\title{
Late Ordovician shelly faunas from Jämtland: palaeocommunity development along the margin of the Swedish Caledonides
}

\author{
PETER DAHLQVIST, DAVID A.T. HARPER \& LINDA WICKSTRÖM
}

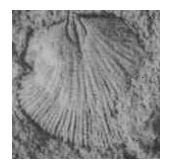

\begin{abstract}
Late Ordovician shelly faunas occur at several localities in the Östersund area of Jämtland (Sweden) and developed against a background of intense and rapid global climate change. In the eastern part, approximately in the middle parts of the Kyrkås Quartzite, and in the western part in the uppermost Kogsta Siltstone changes in faunas and sedimentary patterns provide regional evidence of these global events. In both areas the faunas occur in shale and siltstone facies and are used to effect correlations between the eastern and western parts of the region, which show major differences in facies development. These sub-basins, situated on the margins of a developing mountain belt, reacted differently to global signals providing further evidence of the heterogeneous responses to climate change at the end of the Ordovician Period. - Key words: brachiopods, Hirnantia fauna, Hirnantian, Jämtland, Late Ordovician, Caledonides, palaeocommunity.
\end{abstract}

DAHLQViST, P., HARPER, D.A.T. \& WiCKSTRÖM, L. 2010. Late Ordovician shelly faunas from Jämtland: palaeocommunity development along the margin of the Swedish Caledonides. Bulletin of Geosciences 85(3), 505-512 (5 figures, 1 table). Czech Geological Survey, Prague. ISSN 1214-1119. Manuscript received January 18, 2010; accepted in revised form May 4, 2010; published online July 29, 2010; issued September 30, 2010.

Peter Dahlqvist, GeoBiosphere Science Centre, Lund University, Sölvegatan 12, SE-223 62 Lund, Sweden; peter.dahlqvist@geol.lu.se or peter.dahlqvist@lansstyrelsen.se •David A.T. Harper, Geological Museum, University of Copenhagen, Copenhagen, Denmark • Linda Wickström, Geological Survey of Sweden, Uppsala, Sweden

The end Ordovician marked one of the three greatest Phanerozoic extinction events in the history of life (Bambach 2006). An icehouse interval (Brenchley et al. 1994, Saltzman \& Young 2005) promoted global cooling and glacio-eustatic sea-level fluctuations that significantly changed global biogeographical and depositional patterns (Brenchley et al. 2006). Virtually every section with marine sediments, deposited above storm-wave base, records a regression near the end of the Ordovician and a subsequent transgression within the terminal stage of the system, the Hirnantian (e.g. Cocks \& Rickards 1988, Sheehan 1988). The Jämtland area is developed along strike from the Oslo Region (Brenchley \& Cocks 1982), displays a similar range and diversity of Upper Ordovician-Lower Silurian facies on the edge of the Baltic craton and is partitioned into a set of small basins. However its situation within the Lower Allochthon of the developing Caledonide mountain belt adds a further tectonic dimension to an already complex mosaic of facies. Dahlqvist \& Calner (2004) and Dahlqvist (2004) have recently demonstrated the same patterns of sea level change in the sedimentary development of this part of Caledonian foreland basin as elsewhere in the world. The glacio-eustatic sea-level changes affected the ocean circulation (Sheehan 2001), which together with cooling and a re- striction of habitat space on the shelves had a profound impact on marine faunas leading to a mass extinction, when about $85 \%$ (Jablonski 1991) of marine species became extinct. Currently the mass extinction is partitioned into two biotic events: the first event occurred at the beginning of the glaciation and is associated with the first regressive phase (latest Rawtheyan-early Hirnantian) of the glaciation, while the second event is correlated with the end of the Hirnantian glacial interval (mid-late Hirnantian) and the subsequent transgressive phase (Sheehan 2001). These extinction events approximately coincide with the lower and upper boundaries of the $N$. extraordinarius Zone. Between these crises a brachiopod community termed the Hirnantia fauna characterized most shallow-marine settings at temperate and subtropical latitudes. This fauna, first formally named by Temple (1965), was mainly a cold-water fauna, of near cosmopolitan distribution, which makes it of great importance for both inter- and intra-basinal correlation (e.g. Rong \& Harper 1988, 1999; Cocks 1988; Owen et al. 1991; Chen et al. 2000; Rong et al. 2002). Nevertheless, recent studies (e.g. Harper \& Rong 2008) have demonstrated a significant heterogeneity through the event; not all basins reacted in the same way and there was a considerable range of community associations within the Hirnantia fauna (Rong et al. 2008a). 


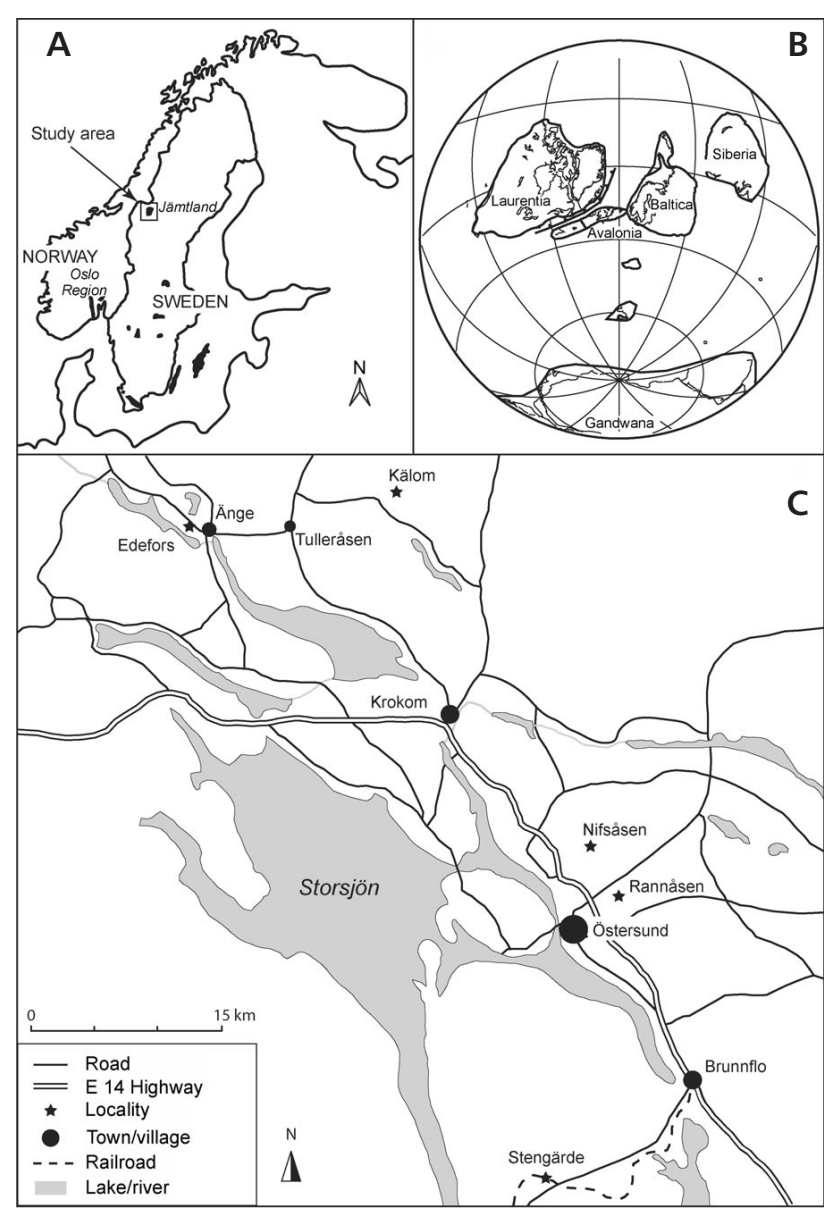

Figure 1. Map of Scandinavia, palaeogeographic setting, and a map of the investigated area. $\bullet \mathrm{A}-$ the main Ordovician and Silurian outcrop areas in Sweden and Norway. • B - Ashgill-Llandovery ( ca $443 \mathrm{Ma}$ ) palaeogeography (modified from Torsvik 1998). $\bullet$ C - map of the Östersund/Lake Storsjön area in Jämtland.

The aim of this paper is to present the Hirnantian shelly faunas from Jämtland, document their composition and diversity and relate their development to the ambient climatic change during the later Ordovician. These data are combined with other available biostratigraphical data and previous sedimentological interpretations, to achieve a more accurate picture of the Late Ordovician depositional patterns along the margin of the emerging Caledonian mountain belt in the Jämtland basin.

\section{The Jämtland area}

The Jämtland area is situated in central Sweden (Fig. 1A), which now forms a part of the Baltic shield. During the late Ordovician, Baltica was situated within southern tropical latitudes (Torsvik 1998; Fig. 1B). Early Palaeozoic sediments were deposited in a foreland basin extended along the western margin of the Baltic craton. Upper Ordovician rocks are scattered throughout the Östersund-Lake Storsjön area (Fig. 1C), where the uppermost Ordovician strata are represented by three formations: the Kogsta Siltstone followed by the Ede Quartzite in the west and the Kyrkås Quartzite in the east. Late Ordovician basin development in Jämtland has been recently investigated providing a substantial amount of new data on this critical area. Sedimentological research on the Upper Ordovician-Lower Silurian Jämtland succession, including biostratigraphically important data includes work by Cherns \& Karis (1995), Dahlqvist (2004), Dahlqvist \& Calner (2004), Dahlqvist \& Bergström (2005), Dahlqvist et al. (2006), and Mötus (2004). Nevertheless, apart from some brief references in the literature (e.g. Bergström 1968) data on the important shelly faunas from this area are sparse. A résumé of the upper Ordovician-Lower Silurian succession in Jämtland is presented below.

Lower-Upper Ordovician (middle Caradoc) strata reflect palaeodepth-related differences between the eastern and western part of the Jämtland basin (Karis 1998, p. 165). The eastern area was dominated by shallow-water carbonate deposition, whereas in the western area, mud and turbidite deposits accumulated in deeper water.

A siltstone facies (the Kogsta Siltstone) marks the start of more uniform deposition over large areas of the basin. The base of the Kogsta Siltstone is dated by graptolites of the Dicranograptus clingani Biozone. The highest fossils occur a few decimetres below the contact with the overlying Ede Quartzite. Biostratigraphic data from the uppermost metres of the Kogsta Siltstone are discussed in this paper. The Kogsta Siltstone consists of dark grey to black shale interbedded with thin to medium bedded siltstones. The Kogsta Siltstone was deposited in an offshore environment. The upward increase of silt and the appearance of primary sedimentary structures indicate a minor increase in depositional energy, reflecting a slight shallowing.

Above the Kogsta Siltstone, depositional patterns become more complex, with the deposition of the Kyrkås Quartzite in the western part of the region and the Ede Quartzite in the eastern part.

The Kyrkås succession contains approximately 90 m of siliciclastic rocks. Two sequences are present, each showing shoreline progradation, commencing with offshore deposited mud and ending with mid-upper shoreface sand (Dahlqvist 2004). The horizon yielding fossils is situated approximately in the middle of the formation, just below a conspicuous $0.75 \mathrm{~m}$ thick bed, termed the Rusty Marker Bed (RMB, Dahlqvist 2004). The RMB occurs in each section at several localities and most probably was a synchronous deposit, which makes it possible to use as a lithological marker horizon. Graptolites, including Normalograptus persculptus have been found approximately $2-3 \mathrm{~m}$ above this siltstone and were referred to the Persculptograptus persculptus Biozone within the uppermost Hirnantian (highest Ordovician) by R.B. Rickards in Cherns \& Karis (1995). 
Table 1. Brachiopods (b) and trilobites (t) recovered from the different localities investigated in this study; elsewhere on Baltica their occurrences in Västergötland (F) and Oslo (G) are indicated. Faunal elements with an asterisk* are typical elements of the Hirnantia fauna according to Rong \& Harper (1988) and Owen et al. (1991). Abbreviation: A - Edefors, B - Stengärde, C - Kälom, D - Nifsåsen, E - Rannåsen, F - Västergötland, G - Oslo.

\begin{tabular}{|c|c|c|c|c|c|c|c|}
\hline Species & A & $\mathrm{B}$ & $\mathrm{C}$ & $\mathrm{D}$ & $\mathrm{E}$ & $\mathrm{F}$ & G \\
\hline * Hirnantia sagittifera (b) & & $x$ & & & & $x$ & $x$ \\
\hline * Dalmanella testudinaria 2 (b) & $x$ & & $x$ & & $x$ & $x$ & $x$ \\
\hline * Eostropheodonta hirnantensis 2 (b) & & & & & $x$ & $x$ & $x$ \\
\hline * Cliftonia sp. (probably C. psittacina) (b) & & $x$ & & & & $\times$ & $\times$ \\
\hline * Kinnella? kielanae 2 (b) & & & & & $x$ & $\times$ & $\times$ \\
\hline Leptaena rugosa $(\mathrm{b})$ & & $x$ & & & & $x$ & $x$ \\
\hline Orbiculoidea sp. cf. radiata 2 (b) & & & & & $\times$ & & \\
\hline Orbiculoidea concentrica (b) & & $x$ & & & & & \\
\hline Leptaenopoma trifidium 1, 2 (b) & & & & & $x$ & $x$ & $x$ \\
\hline * Brongniartella platynota 1, 2 (t) & & $x$ & & & $x$ & & \\
\hline * Dalmanitina (M.) mucronata $1,2(\mathrm{t})$ & $x$ & $x$ & & $\times$ & $x$ & & \\
\hline 'Aegiromena' sp. (b) & $\times$ & & $x$ & $\times$ & & & \\
\hline draboviid? (b) & $x$ & & $x$ & & & $x$ & $\times$ \\
\hline Leptaena sp. (b) & & & & $x$ & $x$ & & \\
\hline Dysprosorthis sp. (b) & & & & $x$ & $x$ & $x$ & $x$ \\
\hline strophomenid (b) & & & & $\times$ & $x$ & & \\
\hline orthid (b) & & & & $x$ & $x$ & & \\
\hline Illaenus? sp. (t) & & & & & $x$ & & \\
\hline proetid (t) & $x$ & & $x$ & & & & \\
\hline
\end{tabular}

The Lower Ede Quartzite (0.9-5 m) has not yielded fossils but based on sedimentology it is interpreted as the latest Ordovician glacio-eustatic low-stand and thus is of Hirnantian age (Dahlqvist \& Calner 2004). This lower part was deposited in a shoreface environment during forced regression (Dahlqvist \& Calner 2004). The Upper Ede Quartzite ( ca $4 \mathrm{~m}$ ) has yielded a conodont fauna of the early-mid Aeronian Pranognathus tenuis Zone (Dahlqvist \& Bergström 2005). The upper part consists of thin bedded, mixed carbonate-siliciclastic sediments deposited in a wave dominated proximal environment (conodont biofacies suggesting BA 1-2, Dahlqvist \& Bergström 2005). The contact between the Lower and Upper Ede Quartzite, probably includes the Ordovician-Silurian boundary interval, appears to be an unconformity associated with a significant hiatus that excludes some or all of the uppermost Hirnantian and at least the Rhuddanian Stage (Dahlqvist \& Calner 2004, Dahlqvist \& Bergström 2005).

To conclude, the Ede and Kyrkås quartzites demonstrate a difference in depositional patterns in the eastern versus the western part of the area. The eastern area shows two regressive events of similar magnitude (with two sequences within the Kyrkås Quartzite, Dahlqvist 2004) while the western area shows one small (within the Kogsta
Siltstone) followed by one major regressive event (lower Ede Quartzite; Dahlqvist \& Calner 2004). The investigated Hirnantian faunas occur, in both the eastern and western areas, a few metres below evidence of the second regressive event. Consequently, the biostratigraphical data available suggest that the observed regressive successions could be related to the Late Ordovician glacio-eustatic sea-level changes but the water-depth signal has been locally modified. The differences in depositional patterns, lateral changes in response to the eustatic movements, are probably related to a palaeoslope, which was inclined from the eastern part, basinward towards the west. Dahlqvist \& Bergström (2005) suggested that the migration of a peripheral bulge over the Ede area could be a possible cause for parts of this depositional pattern.

Transgressive strata from the postglacial sea-level rise are lacking in the eastern area due to later erosion, the Kyrkås Quartzite being the youngest preserved strata, whereas Early Silurian (but not earliest) mixed carbonate-siliciclastic deposits blanketed the unconformity in the west (Dahlqvist 2004, Dahlqvist \& Calner 2004, Dahlqvist $\&$ Bergström 2005). This was followed by a period of more uniform deposition, the Lower Silurian Berge Limestone and the succeeding Bångåsen Shale.

\section{Materials and methods}

The faunas discussed in this paper have been collected at different localities by different geologists during the last decades, numbers given within brackets refer to numbers given later in the text and on the figures; Edefors: (1) P. Dahlqvist (this paper); (2) M.G. Bassett and L. Karis (unpublished collection); Stengärde: (3) J. Bergström (1968); Kälom: (4) L. Wickström and P. Dahlqvist (this paper); Nifsåsen: (5) P. Dahlqvist (this paper) and Rannåsen: (6) P. Dahlqvist (this paper); (7) L. Liljedahl and K. Larsson (unpublished collection); and (8) P. Thorslund (1960).

All of the faunas have been sampled from the shalesiltstone facies. The strata of the Kogsta Siltstone are however more shaly than the interval yielding fossils within the Kyrkås Quartzite. The fossils are poorly preserved or dissolved, leaving only moulds. The main components of the faunas and their sampling levels are shown in Figs 2 and 3. Correlation of the various sections is a presented in Fig. 4. Additionally, the brachiopods and trilobites recovered from each locality are given in Table 1.

\section{Localities and faunas}

Edefors (Kogsta Siltstone), Fig. 2A. - This is the type locality of the Ede Quartzite (7040198/1411158, Swedish National Grid). Several exposures of the Kogsta Siltstone, Ede 


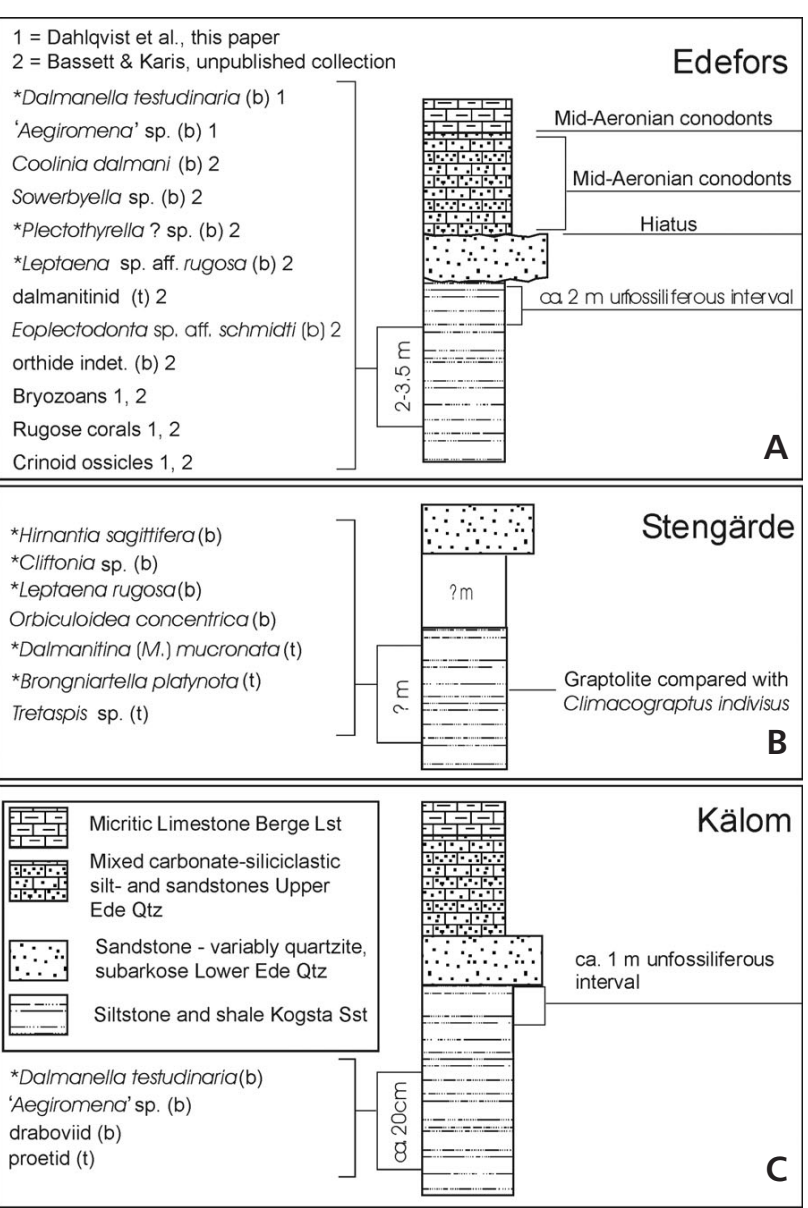

Figure 2. Localities, successions and faunal elements from the Kogsta Siltstone. A - Edefors, B - Stengärde, C - Kälom; t - trilobite, b - brachiopod. Additional biostratigraphical data from Dahlqvist \& Bergström (2005; conodont data in fig. 2a). Faunal elements with an asterisk* are typical elements of the Hirnantia fauna according to Rong \& Harper (1988) and Owen et al. (1991).

Quartzite and Berge Limestone crop out on the slopes of a hill $c a 1 \mathrm{~km}$ SE of Offerdal church. The entire Edefors succession is described in detail in Dahlqvist \& Calner (2004).

Dahlqvist, this paper (1): Several smaller exposures were sampled along the south-facing hillside. The faunas were collected approximately $2-3.5 \mathrm{~m}$ below the contact with the overlying Ede Quartzite. The distance to this contact is approximate because of the nature of the outcrops, scattered exposures in talus accumulations.

This fauna is overwhelmingly dominated by the species of a new brachiopod taxon, very similar to Aegiromena (commonly occurring in concentrations, subsequently referred to 'Aegiromena') and Dalmanella testudinaria (see Jin \& Bergström 2010 for a revision of this important species) but it also contains the trilobite Dalmanitina (Mucronaspis) mucronata, rugose corals and crinoid fragments. This deep-water facies is either of latest Rawtheyan or early Hirnantian age.
Reference samples are stored at the Department of Geology, Lund University, Sweden.

Bassett \& Karis, unpublished (2): The fauna was collected at approximately $4.5 \mathrm{~m}$ below the contact with the Ede Quartzite and includes the following: Coolinia dalmani, Plectothyrella? sp., Leptaena sp. [?aff. rugosa], indeterminate dalmanellids, an indeterminate orthid [coarse ribbed - similar to either Sulevorthis or Nicolella], Eoplectodonta aff. schmidti, Sowerbyella sp., Dalmanella sp. [?cf. testudinaria], 'dalmanitinid' trilobites, solitary rugose corals, crinoid stems, and indeterminate bryozoans (M.G. Bassett, pers. comm. 2004). This fauna is most probably of Hirnantian age.

Stengärde (Kogsta Siltstone), Fig. 2B. - This is a railway section (6988632/1440559, Swedish National Grid) located ca $300 \mathrm{~m} \mathrm{~N}$ of the railroad bridge along the track. This section exposes only the Kogsta Siltstone, and there is no sign of any succeeding quartzite. The Ede Quartzite can however be found in the area. The thickness of the strata is difficult to measure due to folding. The Kogsta Siltstone here contains only a few calcareous nodules.

Bergström 1968 (3): Bergström (1968) collected a few specimens of brachiopods and trilobites from a mudstone bed at Stengärde that was correlated with the Dalmanitina Beds, within part of the Kogsta Siltstone. Since the Ede Quartzite is not present at this locality, the precise stratigraphical position of the collection is uncertain.

The fauna includes the brachiopods Cliftonia sp. (probably C. psittacina), Hirnantia sagittifera, Leptaena rugosa, Orbiculoidea concentrica and the trilobites Dalmanitina (Mucronaspis) mucronata, Brongniartella platynota. Re-examination of the material during this study was unable to confirm the presence of Hirnantia sagittifera. Nevertheless, this fauna is almost certainly of Hirnantian age.

The fauna shows similarities to the Hirnantia Association found in the central Oslo Region (Brenchley \& Cocks 1982), but lacks some of the key elements of the Norwegian association such as Dalmanella testudinaria, Hindella cassidea, and Eostropheodonta hirnantensis.

Reference samples are stored in the Department of Geology, Lund University, Sweden.

Kälom (Kogsta Siltstone), Fig. 2C. - Two neighbouring localities (E1425014/N7042266 and E1425617/N7042740) have yielded material. Exposures of the uppermost Kogsta Siltstone, the lower and upper Ede Quartzite and the lowermost Berge Limestone occur in an enclosed pasture approximately $200 \mathrm{~m}$ from the road through the village Öster Ulvsås, approximately $6 \mathrm{~km}$ from road 340 .

Wickström \& Dahlqvist, this paper (4): The fauna was collected at two localities. They are similar in composition and were collected approximately $0.5-1 \mathrm{~m}$ below the contact to the Ede Quartzite. The siltstone is dominated by 
Dalmanella testudinaria and a large species of 'Aegiromena' commonly occurring in concentrations. Additional elements include a possible draboviid brachiopod and a proetid trilobite. This deep-water facies is of either latest Rawtheyan or early Hirnantian age. Reference samples are stored at the Swedish Geological Survey (SGU), Uppsala, Sweden.

Nifsaisen (Kyrkås Quartzite), Fig. 3A. - The main locality is in Nifsåsen Quarry (701350/144325, Swedish National Grid) is situated $c a 5.5 \mathrm{~km}$ NNE of Östersund, $c a 2 \mathrm{~km} \mathrm{NE}$ of the main road (E14). This is a large quarry with near vertical strata in high, steep walls. The entire Kyrkås Quartzite succession was described in detail by Dahlqvist (2004). The Nifsåsen quarry is still in production.

Dahlqvist, this paper (5): The fauna was collected just below a marker bed (the RMB, Dahlqvist 2004) in an interval of about $1 \mathrm{~m}$, at the $\mathrm{SW}$-wall. The investigated fauna includes species of the brachiopods 'Aegiromena', Dysprosorthis sp. and Leptaena together with indeterminate orthid and strophomenid shells and the trilobites Dalamanitina (Mucronaspis) mucronata. Additional fossils include bivalves, gastropods, hyolithids, orthocones, and one graptolite. Reference samples are stored in the Department of Geology, Lund University, Sweden.

Rannåsen (Kyrkås Quartzite), Fig. 3B. - The key locality is in Rannåsen Quarry (701020/144425, Swedish National Grid) is located $c a 2.5 \mathrm{~km} \mathrm{NE}$ of Östersund, $c a 1 \mathrm{~km} \mathrm{E}$ of the main road (E14). The section at Rannåsen is one of the most examined and noted successions in the Jämtland area, e.g. Thorslund (1943, 1960), Karis \& Larsson (1982), Cherns \& Karis (1995) Dahlqvist (2004) and Wickström et al. (2007). The Rannåsen quarry is still in production.

Dahlqvist, this paper (6): Fossils were sampled at the NE corner of the quarry in an approximately $1 \mathrm{~m}$ thick interval below the RMB.

The investigated fauna includes the brachiopod genera 'Aegiromena' and the trilobite genera Brongniartella and Mucronaspis. Reference samples are stored in the Department of Geology, Lund University, Sweden.

Liljedahl \& Larsson, unpublished (7): Thirty-two species of invertebrates were recorded from this locality, mostly as in situ samples from below the RMB but some from loose blocks. Eighteen species (56\%) are molluscs (15 bivalves, 2 cephalopods, 1 gastropod), $8(25 \%)$ are brachiopods (2 nonarticulate, 6 'articulate'), 3 (9\%) trilobites and one (3\%) graptolite, hyolithid, and tentaculitid, respectively. Bivalves are by far the most dominant faunal element and constitute $47 \%$ of the 252 specimens recorded.

The high proportion of articulated bivalves suggests preservation in situ. The fauna includes the brachiopods Eostropheodonta hirnantensis, Dalmanella testudinaria, Kinnella? kielanae, Orbiculoidea cf. radiata, and Leptaenopoma trifidium [Note: Some authorities have synony-

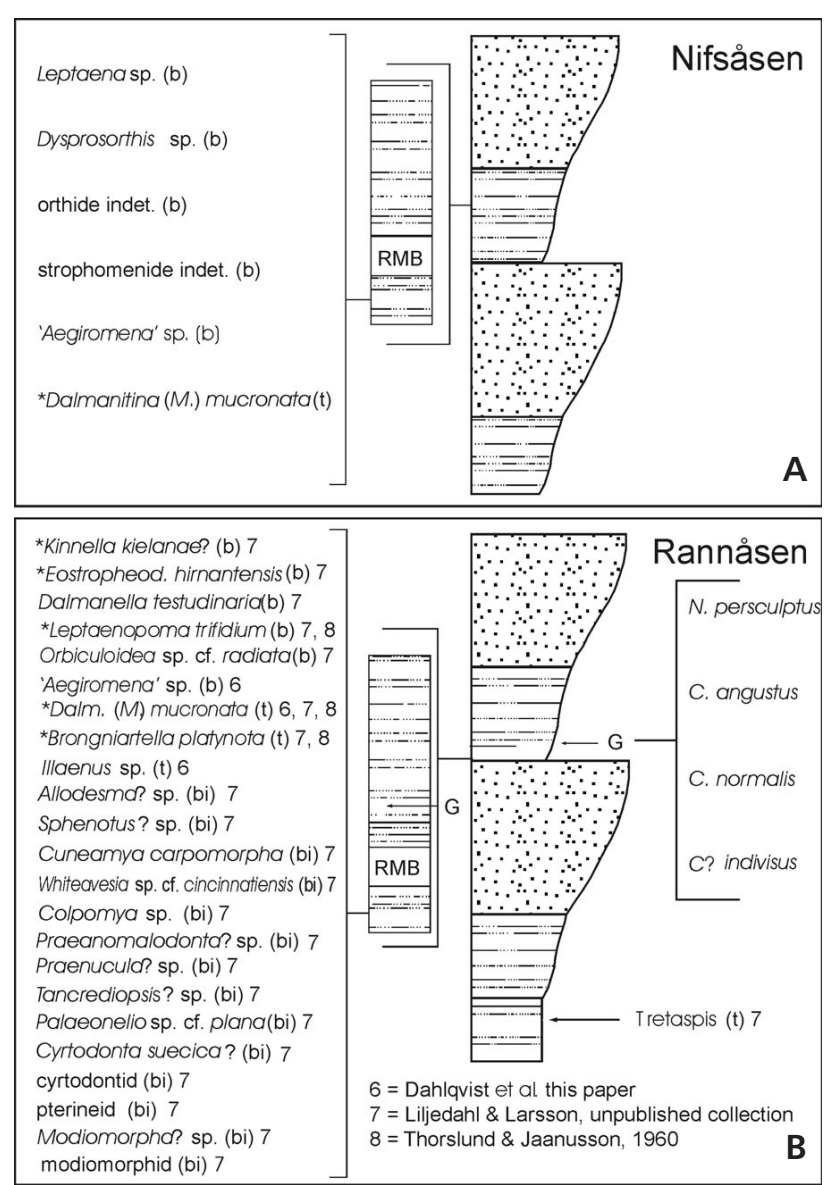

Figure 3. Locality successions and fauna elements from the Kyrkås Quartzite. A - Nifsåsen, B - Rannåsen; $\mathrm{t}$ - trilobite, b - brachiopod, bi bivalve. Additional biostratigraphical data from Cherns \& Karis (1995; graptolite data in fig. 3b). Faunal elements with an asterisk* are typical elements of the Hirnantia fauna according to Rong \& Harper 1988 and Owen et al. (1991).

mised Leptaenopoma trifidium with Leptaena rugosa; here we have retained the original identifications by Bergström (1968) where appropriate], the trilobites Brongniartella platynota, and Dalmanitina (Mucronaspis) mucronata and the bivalves Allodesma? sp., a modiomorphid, Modiomorpha? sp., a pterineid, a cyrtodontid, Cyrtodonta suecica?, Palaeonelio cf. plana, Tancrediopsis? sp., Praenucula? sp., Sphenotus? sp., Praeanomalodonta? sp., Colpomya sp., Whiteavesia cf. cincinnatiensis and Cuneamya carpomorpha. According to John Cope, National Museum of Wales, Cardiff (pers. com.) the bivalves are mostly infaunal taxa, but with some epibyssate benthos and is characteristic of a shallow water shelf assemblage. Reference samples are stored in the Department of Geology, Lund University, Sweden.

Brenchley \& Cocks (1982) recovered a similar fauna from the central Oslo Region that they assigned to their Trematis-Bivalve assemblage. This fauna is dominated by modiolopsid bivalves and the large brachiopod Trematis 


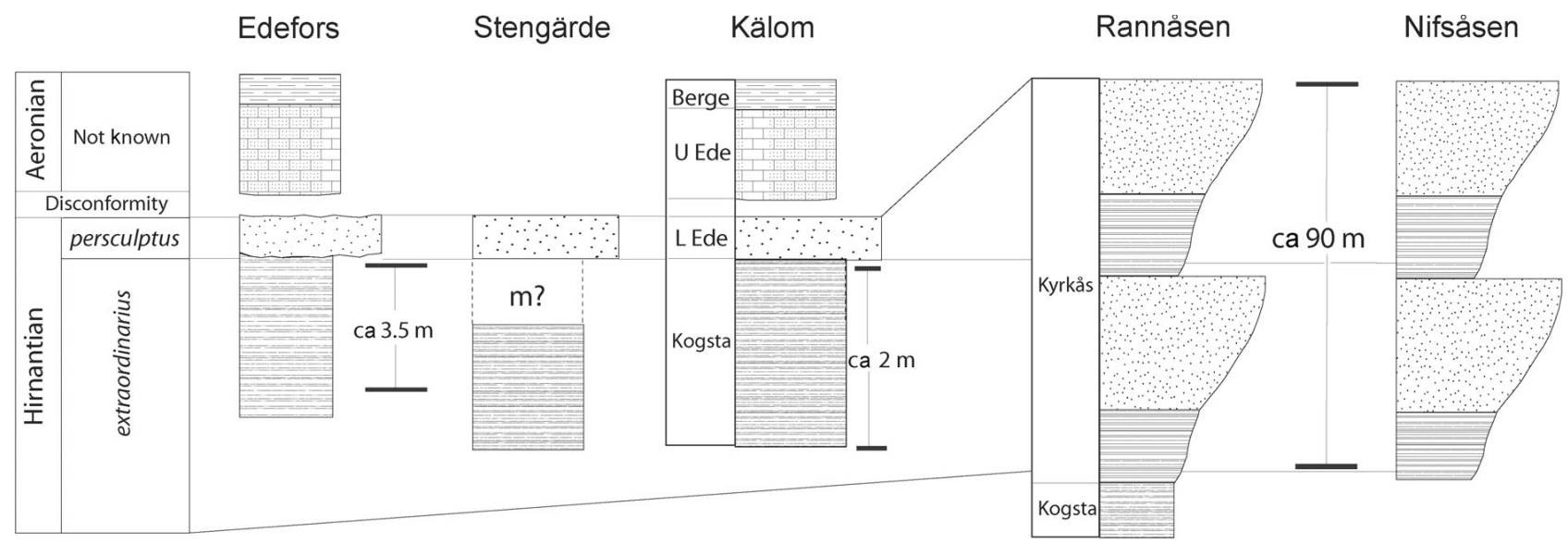

Figure 4. Correlation of the sections at Edefors, Stengärde, Kälom, Nifsåsen and Rannåsen. Based on Dahlqvist (2005, fig. 6).

norvegica, and includes a few specimens of the brachiopods Hindella cassidea, Hirnantia sp., Eostropheodonta sp., Leptaena sp. and the bivalves Pterinea sp. and Cuneamya? sp. This fauna occurs above beds with the Hirnantia association at the level where inner shelf mudstone facies passes into the sandy lower shoreface facies. In a recent study of the uppermost Ordovician bilvalves from the Prague Basin Kříž \& Steinová (2009) describes two different comunities containing bivalves; the Modiolopsis Comunity Group, a low diversified community from coarse storm generated sandstones and, the Hirnantia saggittifera-Sluha kosoviensis Comunity Group, a high diversified fauna living in a soft bottom environment with a high organic content. The Rannåsen fauna occupied a more muddy environment, that may explain the differences in composition between this locality and most of the others.

Thorslund 1960 (8): The reported fauna includes the brachiopod Leptaenopoma trifidum and the trilobites Dalmanitina (Mucronaspis) mucronata, Brongniartella platynota and a species of Illaenus. Thorslund (1960) did not mention where he collected the material, but the fauna is probably Hirnantian in age.

\section{Discussion}

The faunas can be partitioned into two groups corresponding to an east west transect across the sub-basins (see Fig. 1c). The sections at Edefors and Kälom are dominated by Dalmanella testudinaria and a species of 'Aegiromena' together with the trilobite Dalmanitina (Mucronaspis) mucronata. The occurrences of a possible species of Plectothyrella together with Coolinia dalmani support a correlation with the Hirnantian rather than the Rawtheyan (upper Katian). Both faunas occur in the siltstones and shales of the upper part of the Kogsta Siltstone and are succeeded by the quartzites of the Lower Ede Quartzite. At Stengärde elements of the Hirnantia fauna, including Hirnantia sagittifera, Cliftonia psittacina together with Dalmanitina
(Mucronaspis) mucronata and Brogniartella platynota occur in siltstones and shales of the upper Kogsta Siltstone.

At Nifsåsen and Rannåsen in the vicinity of Östersund, the fauna occurs just below the RMB within the Kyrkås Quartzite. At Rannåsen the brachiopod assemblage is typified by some key elements of the Hirnantia fauna together with a diverse bivalve fauna whereas at Nifsåsen the fauna is much less diverse with only a few brachiopods including Dysprosorthis and Leptaena.

There are, however, a number of unusual aspects of the Jämtland faunas and their settings. First there is considerable variation in faunal composition in the assemblages over a relatively small area of some $540 \mathrm{~km}^{2}$. This suggests differences in both water depth and perhaps substrate associated with an uneven seafloor. Second the Hirnantia faunas in contrast to many other parts of the world do not appear to occur against a background of substantial regression; the first evidence (in this case forced regression) of major regression occurs above the Hirnantia faunas. Dahlqvist \& Calner (2004) suggested that both local subsidence and patterns of sediment production and delivery might have been sufficient to mask these global signals of regression and transgression. In the eastern parts of the basin deeper water facies (mid to upper shoreface deposits, Dahlqvist 2004) persist in the Kyrkås Quartzite, probably until the Rhuddanian. In the west, however, shallow water quartzitic sandstone of the Ede Quartzite was deposited during a forced regression. These sediments were followed by emergence and/or non-deposition leading to a hiatus (Dahlqvist \& Calner 2004). Dahlqvist \& Bergström (2005) suggested that local uplift was associated with the development of a peripheral bulge along this part of the Baltic margin.

Such regional heterogeneity is not unusual along the margins of the Caledonian orogen. Along strike in the Oslo Region there is similar variation. In the central, deeper parts of the Oslo basin, the lower Hirnantian is characterized by at least three, relatively diverse, variants of the typical Hirnantia (Kosov Province) fauna; whereas the summit of 
the Ashgill (Hirnantian) succession contains elements of the mid-Continent (Edgewood Province) in channel fill deposits (Brenchley \& Cocks 1982). A relict Ordovician brachiopod fauna persisted during the earliest Silurian in the deeper parts of the Oslo basin (Baarli \& Harper 1986). Farther north in the Ringerike district, the Hirnantian is probably missing (Harper, personal observations; Thomsen et al. 2007) whereas in the adjacent Hadeland district the Ordovician-Silurian boundary strata are represented by shallow-water, siliciclastic facies with low diversity brachiopod and trilobite faunas (Owen et al. 2008). Basement faulting in the Oslo Region, has been invoked to explain the marked variation in local facies patterns associated with the development of the adjacent Caledonian orogen (Bruton \& Harper 1988).

\section{Global context of the Jämtland faunas}

Initial global reviews of the Hirnantian brachiopod and trilobite faunas (e.g. Rong 1984, Rong \& Harper 1988, Owen 1986, Owen et al. 1991) indicated geographical together with depth and substrate controls on their distributions. Within the Brachiopoda three provinces were established (Rong \& Harper 1988): The Bani (high latitude), the Kosov (temperate to subtropical latitudes) and the Edgewood (low latitudes); the typical Hirnantia fauna occupied the Kosov Province. Within the Kosov Province there was also a clear depth zonation with the shallow water, nearshore facies dominated by rhynchonellide brachiopods, and the shallow to midshelf depths occupied by associations dominated by species of Eostropheodonta, Hindella and Hirnantia and the deep water by the species of the strophomenide genera Aegiromena and Paromalomena. These patterns have been largely confirmed by more modern studies (e.g. Rong et al. 2008a). A cluster analysis (Fig. 5) of a subset of the available dataset of Hirnantian brachiopod faunas (see Rong \& Harper 1988, Hammer et al. 2001) places the Jämtland faunas with the Kosov Province. Significantly, however, while Hirnantia and Mucronaspis faunas continued to dominate the western margin of Baltica during the Late Ordovician, elements of the Laurentian Edgewood Province were already present in Östergötland (Rong et al. 2008b) and a typical Edgewood fauna occupied latest Ordovician carbonate environments in the Oslo Region (Brenchley \& Cocks 1982). Moreover the presence of a taxon closely related to Aegiromena confirms the presence of deeper-water facies, mainly siliciclastic, in the Jämtland basins, just adjacent to and partly within the developing Caledonide mountain belt.

\section{Conclusions}

New collections and reassessment of existing collections from the Upper Ordovician rocks of the Jämtland area con-

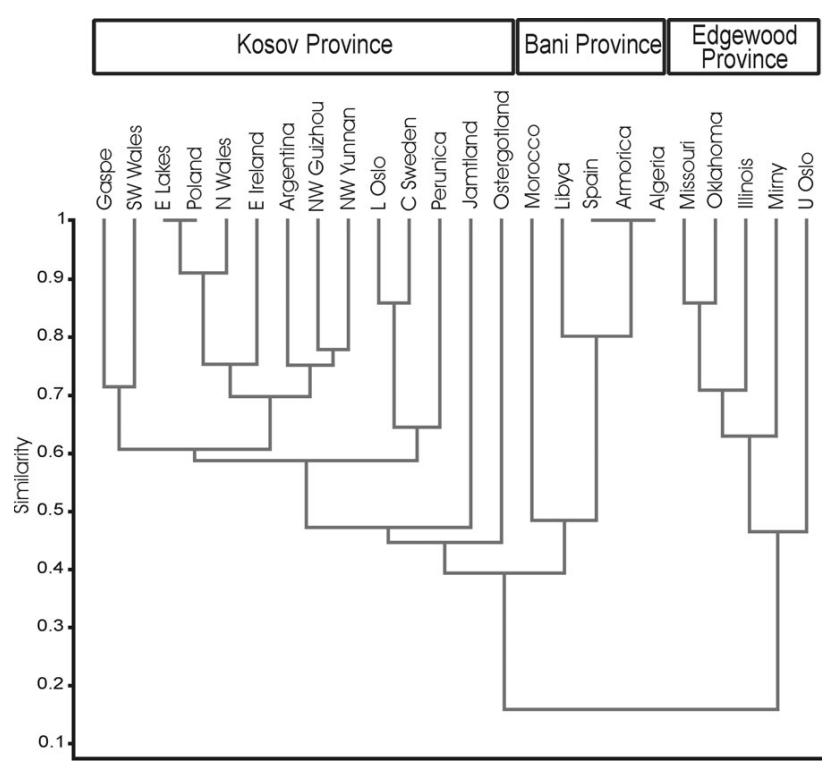

Figure 5. Cluster analysis of a partial dataset of Hirnantian brachiopod global distributions (data modified and updated from Rong \& Harper 1988; see also http://folk.uio.no/ohammer/past/study7.html) using Dice coefficient and average weighted pair clustering. The three main Hirnantian provinces are indicated, with the Jämtland faunas associating with the Kosov Province.

firm the development of variants of the Hirnantia brachiopod fauna on the western edge of Baltica. Most of the taxa are typical of the temperate to subtropical Kosov Province (Rong \& Harper 1988). There is nevertheless significant variation in the composition of these faunas across the relatively small study area, suggesting local contrasts in depth and substrate along this part of the Caledonian margin. Here tectonic processes have combined with eustatic changes in sea level to generate a range of heterogeneous environments and associated faunal communities across a relatively small area.

\section{Acknowledgements}

We are grateful to L. Liljedahl and K. Larsson for providing unpublished information about the Rannåsen fauna, and M. Bassett and L. Karis for unpublished information about the Edefors fauna. J. Cope is thanked for personal communications regarding the bivalve fauna. The Royal Physiographical Society (Kungliga Fysiografiska Sällskapet) in Lund and the Royal Swedish Academy of Sciences (Kungliga Vetenskapsakademien) are thanked for grants to PD, which made fieldwork, travel and analyses possible. Harper acknowledges financial support from the Danish Council for Independent Research (FNU). We also wish to acknowledge IGCP 503.

\section{References}

BAARLI, B.G. \& HARPER, D.A.T. 1986. Relict Ordovician brachiopods in the lower Silurian of Asker, Oslo Region, Norway. Norsk Geologisk Tidsskrift 66, 87-98. 
BAMBACH, R.K. 2006. Phanerozoic biodiversity mass extinctions. Annual Review of Earth and Planetary Sciences 34, 127-155. DOI 10.1146/annurev.earth.33.092203.122654

BERGSTRÖM, J. 1968. Upper Ordovician brachiopods from Västergötland, Sweden. Geologica et Palaeontologica 2, 1-35.

BRENCHLEY, P.J. \& COCKS, L.R.M. 1982. Ecological associations in a regressive sequence: the latest Ordovician of the Oslo-Asker district, Norway. Palaeontology 25, 783-815.

BRENCHLEY, P.J., MARSHALl, J.D., CARDEN, G.A.F., Robertsson, D.B.R., LONG, D.G.F., MEIDLA, T., HinTs, L. \& ANDERSON, T.F. 1994. Bathymetric and isotopic evidence for a short-lived Late Ordovician glaciation in a greenhouse period. Geology 22, 295-298. DOI 10.1130/0091-7613(1994)022<0295:BAIEFA > 2.3.CO;2

BrENCHLEY, P.J., MARShall, J.D., HARPER, D.A.T., BUTLER, C.J. \& UNDERWOOD, C.J. 2006. A late Ordovician (Hirnantian) karstic surface in a submarine channel, recording glacio-eustatic sea-level changes: Meifod, central Wales. Geological Journal 41, 1-22. DOI 10.1002/gj.1029

BRUTON, D.L. \& HARPER, D.A.T. 1988. Arenig-Llandovery stratigraphy and faunas across the Scandinavian Caledonides. Geological Society, London, Special Publications 38, 247-268.

Chen, X., Rong, J-Y., Mitchell, C.E., HARPer, D.A.T., FAN, J-X., ZHANG, Y.-D., LI, R.-Y. \& WANG, Y. 2000. Late Ordovician to earliest Silurian graptolite and brachiopod biozonation from the Yangtze region, South China with a global correlation. Geological Magazine 137, 623-650.

DOI 10.1017/S0016756800004702

CHERNS, L. \& KARIS, L. 1995. Late Ordovician-Early Silurian transgressive sedimentation in the Jämtland basin, central Swedish Caledonides. GFF 117, 23-30. DOI 10.1080/11035899509546193

COCKS, L.R.M. \& RICKARDS, R.B. 1988. A global analysis of the Ordovician-Silurian Boundary. Bulletin of the British Museum (Natural History), Geology 43, 1-394.

DAHLQVIST, P. 2004. Late Ordovician (Hirnantian) depositional pattern and sea-level change in shallow marine to shoreface cycles in central Sweden. Geological Magazine 141, 1-12. DOI 10.1017/S0016756804009446

DAHLQVIST, P. 2005. Synthesis, 7-18. In Late Ordovician-Early Silurian facies development and stratigraphy of Jamtland, central Sweden. Litholund theses 6. Doctoral thesis, Department of Geology, Lund University.

DAHLQVIST, P. \& BERGSTRÖM, S.M. 2005. The lowermost Silurian of Jämtland, central Sweden: conodont biostratigraphy and correlation and biofacies. Transactions of the Royal Society of Edinburgh: Earth Science 9, 1-19.

DAHLQVist, P. \& CALNER, M. 2004. Late Ordovician palaeoceanographic changes as reflected in the Hirnantian-early Llandovery succession of Jämtland, Sweden. Palaeogeography, Palaeoclimatology, Palaeoecology 210, 149-164.

DAHLQvist, P., JOHANSSON, L. \& SÖDERLUnd, U. 2006. Provenance of Late Ordovician clastic sedimentary rocks in Jämtland, central Sweden. GFF 128, 311-320. DOI 10.1080/11035890601284311

HAMMER, Ø., HARPER, D.A.T. \& RYAN, P.D. 2001. PAST: Paleontological statistics software package for education and data analysis. Palaeontologia Electronica 4, 1-9.

HARPER, D.A.T. \& RONG, J.-Y. 2008. Completeness of the Hirnantian brachiopod record: Spatial heterogeneity through the end Ordovician extinction event. Lethaia 41, 195-197. DOI 10.1111/j.1502-3931.2008.00098.x

JABLONSKI, D. 1991. Extinctions: a paleontological perspective. Science 253, 754-757. DOI 10.1126/science. 253.5021.754

JIN, J. \& BERGSTRÖM, J. 2010. True Dalmanella and taxonomic im- plications for some Late Ordovician dalmanellid brachiopods from North America. GFF 132, 1-12.

KARIS, L. \& LARSSON, K. 1982. Jämtland road-log. Palaeontological Contributions from the University of Oslo 279, 64-76.

KARIS, L. 1998. Jämtlands östliga fjällberggrund, 1-184. In KARIS, L. \& STRÖMBERG, G.B. (eds) Beskrivning till berggrundskartan över Jämtlands län. Del 2: Fjälldelen, Geological Survey of Sweden Ca 53 (2).

KŘíž, J. \& STEINOVÁ, M. 2009. Uppermost Ordovician bivalves from the Prague Basin (Hirnantian, Perunica, Bohemia). Bulletin of Geosciences 84(3), 409-436. DOI 10.3140/bull.geosci.1141

MÖTUS, M.-A. 2004. Tabulate corals from the Lower Silurian of Jämtland (Sweden). GFF 126, 339-352. DOI 10.1080/11035890401264339

OWEN, A.W. 1986. The uppermost Ordovician (Hirnantian) trilobites of Girvan, SW Scotland with a review of coeval trilobite faunas. Transactions of the Royal Society of Edinburgh: Earth Sciences 77, 231-239.

OWEN, A.W., HARPER, D.A.T. \& RONG, J-Y. 1991. Hirnantian trilobites and brachiopods in space and time. Geological Survey of Canada, Paper 90-9, 64-76.

OWEN, A.W., HARPER, D.A.T. \& HEATH, R.A. 2008. A route to recovery: The early Silurian shallow water shelly fauna in the northern Oslo basin. Lethaia 41, 173-184. DOI 10.1111/j.1502-3931.2008.00109.x

RONG, J.-Y. 1984. Distribution of the Hirnantia fauna and its meaning, 101-112. In BRUTON, D.L. (ed.) Aspects of the Ordovician System. Universitetsforlaget, Oslo.

RONG, J.-Y. \& HARPER, D.A.T. 1988. A global synthesis of the latest Ordovician Hirnantian brachiopod faunas. Transactions of the Royal Society of Edinburgh; Earth Sciences 79, 383-402.

RONG, J.-Y, JIN, J., ZHAN, R.-B. \& BERGSTRÖM, J. 2008b. The earliest known Stegerhynchus (Rhynchonellida, Brachiopoda) from the Hirnantian strata (uppermost Ordovician) at Borenshult, Östergötland, Sweden. GFF 130, 21-30.

DOI 10.1080/11035890801301021

SALTZMAN, M.R \& YOUNG, S.A. 2005. Long-lived glaciation in the Late Ordovician? Isotopic and sequence-stratigraphic evidence from western Laurentia. Geology 33, 109-112.

DOI 10.1130/G21219.1

SHEEHAN, P.M. 1988. Late Ordovician events and the terminal extinction. New Mexico Bureau of Mineral Resources Memoir 44, 405-415.

SHEEHAN, P.M. 2001. The Late Ordovician mass extinction. Annual Reviews Earth Planetary Science 29, 331-364.

DOI 10.1146/annurev.earth.29.1.331

TEMPLE, J.T. 1965. Upper Ordovician brachiopods from Poland and Britain. Acta Palaeontologica Polonica 10, 379-427.

THOMSEN, E., JIN, J. \& HARPER, D.A.T. 2007. Early Silurian brachiopods (Rhynchonellata) from the Sælabonn Formation of the Ringerike district, Norway. Bulletin of the Geological Society of Denmark 53, 111-126.

THORSLUND, P. 1943. Gränsen Ordovicium-Silur inom Storsjöområdet i Jämtland. Sveriges Geologiska Undersökning C 455, 1-19.

ThORSLUND, P. 1960. Notes on the Cambro-Silurian of Jämtland, 35-51. In THORSLUnd, P. \& JAANusson, V. (eds) The Cambrian, Ordovician, and Silurian in Västergötland, Närke, Dalarna, and Jämtland, International Geological Congress XX1 Session, Guide to excursions A 23 and C 19.

ToRSVIK, T.H. 1998. Palaeozoic Palaeogeography: A North Atlantic viewpoint. GFF 120, 109-118. DOI 10.1080/11035899801202109

WICKSTRÖM, L.M., FRISK, Å.M. \& DAHLQVIST, P. 2007. Locality descriptions, the Storsjön Area. SGU Rapporter och meddelanden 128. 